Jurnal Tabarru' : Islamic Banking and Finance

Volume 3 Nomor 1, Mei 2020

p-ISSN 2621-6833

e-ISSN 2621-7465

\title{
PENGARUH FAKTOR CAMEL TERHADAP PROFITABILITAS (ROA) PADA BANK UMUM SYARIAH PERIODE 2014-2018
}

\author{
Mutiara Mustafa \\ Fakultas Agama Islam (FAI), Universitas Islam Riau \\ Email:mutiaramstf@gmail.com
}

\begin{abstract}
ABSTRAK
Penelitian ini dilakukan untuk menguji perbandingan tingkat bank konvensional dan bank umum syariah dengan menggunakan ROA periode 2014-2018. Populasi penelitian ini adalah bank umum syariah yang terdaftar di Bank Indonesia yaitu sebanyak 14 perusahaan. Berdasarkan teknik purposive sampling didapatkan sampel 7 perusahaan. Penelitian ini menggunakan metode dokumentasi yang di dapat dari laporan keuangan yang dipublikasikan di website www.ojk.go.id dan www.bi.go.id. Hasil penelitian menunjukkan bahwa : (1) CAR berpengaruh positif dan signifikan terhadap ROA, (2) BOPO berpengaruh negatif dan tidak signifikan terhadap ROA, (3) NPL berpengaruh negatif dan tidak signifikan terhadap ROA, (4) NET berpengaruh negatif dan tidak signifikan terhadap ROA.
\end{abstract}

Katakunci : CAMEL, Capital Adequacy Ratio (CAR), Return On Asset (ROA), Beban Operasional terhadap Pendapatan Operasional (BOPO), Non Performing Loan (NPL), Net Interest Margin (NIM).

\begin{abstract}
This study was conducted to examine the comparison of the level of conventional banks and Islamic commercial banks using ROA for the period 2014 - 2018. The population of this study is Islamic commercial banks registered at Bank Indonesia, as many as 14 companies. Based on purposive sampling technique, a sample of 7 companies was obtained. This research uses the documentation method obtained from the published financial statements on the website www.ojk.go.id and www.bi.go.id. The results showed that: (1) CAR has positive and significant effect on ROA, (2) BOPO has negative and not significant effect on ROA, (3) NPL has negative and not significant effect on ROA, (4) NET has negative and not significant effect on ROA.
\end{abstract}

Keywords : CAMEL, Capital Adequacy Ratio (CAR), Return On Assets (ROA), Operational Expense to Operational Revenue (BOPO), Non Peforming Loans (NPL), Net Interest Margin (NIM). 


\section{PENDAHULUAN}

Bank adalah lembaga keuangan yang memiliki fungsi menghimpun dana dari masyarakat dan menyalurkannya kembali kepada masayarakat. Kata bank itu sendiri berasal dari kata banque dalam bahasa prancis dan banco dalam bahasa Italia yang artinya peti atau lemari. Semakin berkembang pesatnya kegiatan ekonomi, semakin berkembang pula lembaga keuangan (Bank) di Indonesia. Salah satu jenis Bank yang mulai menjadi perhatian dan diminati masyarakat pada masa kini adalah Bank Syariah. Menurut UU No. 72 Tahun 1992 yang disempurnakan pada UU No. 10 tahun 1998 tentang Perbankan Syariah, menetapkan bahwa perbankan syariah di Indonesia menganut dual banking system. Adanya peraturan perundangan tersebut tentu saja akan memperkuat eksistensi dari Bank Syariah, karena Bank Konvensional diperbolehkan untuk membuka unit yang berbasis syariah. Tujuan didirikannya sebuah bank salah satunya adalah pencapaian keuntungan yang maksimal.

Bank Umum Syariah dalam menjalankan kegiatan usahanya terutama dalam hal mendapatkan keuntungan, selalu berhadapan dengan perkembangan kinerja Bank Syariah secara financial maupun secara non financial sehingga diperlukan adanya financial management yang baik. Salah satunya dengan pengelolaan atas aktiva yang dimiliki agar Bank mampu mencapai pendapatan maupun menekan biaya-biaya yang dikeluarkan. Pendapatan yang diterima oleh bank digunakan untuk membiayai kegiatan usaha maupun ekspansi di masa yang akan datang. Salah satu rasio yang dapat digunakan Bank Syariah untuk mengukur keberhasilan manajemen dalam menghasilkan laba adalah Return On Asset (ROA). Keberhasilan manajemen laba yang baik pada suatu bank dapat diidentifikasi dari besarnya nilai ROA yang mengalami peningkatan dari satu periode ke periode tertentu. Namun, tidak demikian halnya yang terjadi pada Bank Umum Syariah yang dijadikan objek penelitian ini.

Greuning dan Iqbal (2011), mendefinisikan profitabilitas merupakan "indikator dari posisi kompetitif sebuah Bank di pasar perbankan serta kualitas manajemennya". Bank dalam mencapai tingkat profitabilitas yang cukup, perlu melakukan pengelolaan pada kinerja keuangannya. Salah satu rasio yang digunakan dalam penilaian kinerja keuangan adalah ROA. Sesuai dengan Surat Edaran Bank Indonesia Nomor 9/24/ DPbS tahun 2007, Return On Asset (ROA) merupakan rasio yang digunakan untuk mengukur keberhasilan manajemen dalam menghasilkan laba secara keseluruhan.

Beberapa penelitian yang sama pada penelitian, Wahi Laily (2014) dalam penelitiannya menyatakan bahwa CAR, NPF dan FDR berpengaruh positif tidak signifikan terhadap profitabilitas (ROA) pada Bank Umum Syariah. Sedangkan NOM berpengaruh positif dan signifikan. ROE berpengaruh negatif dan tidak signifikan.

Adapun rumusan masalah dalam penelitian ini yaitu:

(1) Apakah terdapat pengaruh Capital Adequacy Ratio (CAR) terhadap Return On Asset (ROA) pada Bank Umum Syariah 2014-2018?

(2) Apakah terdapat pengaruh Beban Operasional terhadap Pendapatan Oprasional (BOPO) terhadap Return On Asset (ROA) pada Bank Umum Syariah 2014-2018?

(3) Apakah terdapat pengaruh Non Forming Loan (NPL) terhadap Return On Asset (ROA) pada Bank Umum Syariah 20142018 ?

(4) Apakah terdapat Net Interest Margin (NIM) terhadap Return On Asset (ROA) pada Bank Umum Syariah 2014-2018 ? 


\section{TINJAUAN PUSTAKA}

\section{Capital Assets Ratio (CAR)}

CAR merupakan rasio keuangan untuk mengukur kecukupan modal yang dimiliki oleh suatu bank. Semakin tinggi CAR maka semakin kuat kemampuan bank untuk menanggung risiko, dan bank mampu memberikan kontribusi yang cukup besar bagi profitabilitas bank (ROA). Rasio CAR sebagaimana terdapat dalam SE Nomor: 6/23/DPNP dapat dirumuskan sebagai berikut:

$$
\mathrm{CAR}=\frac{\text { Laba setelah Pajak }}{\text { Total Asset }} \times 100 \%
$$

\section{Profitabilitas (ROA)}

Profitabilitas atau Return On Asset (ROA) ini merupakan rasio untuk menilai kemampuan perusahaan dalam mencari keuntungan. Penilaian kinerja keuangan bank yang dapat dinilai oleh pendekatan analisis rasio keuangan inilah juga memberikan ukuran tingkat efektivitas manajemen suatu perusahaan. Semakin besar Return On Asset (ROA) menunjukkan kinerja perusahaan semakin baik, karena return semakin besar.

$$
\mathrm{ROA}=\frac{\text { Laba Bersih setelah Pajak }}{\text { Total Aktiva }} \times 100 \%
$$

\section{Belanja Operasional terhadap Pendapatan Operasional (BOPO)}

BOPO (Belanja Operasional terhadap Pendapatan Operasional) merupakan rasio yang menggambarkan efisiensi perbankan dalam melakukan kegiatannya. Belanja operasional adalah biaya bunga yang diberikan pada nasabah sedangkan pendapatan operasional adalah bunga yang didapatkan dari nasabah. Semakin kecil nilai BOPO artinya semakin efisien perbankan dalam beroperasi. BOPO dihitung dengan rumus sebagai berikut:

$$
\text { Bopo }=\frac{\text { Belanja Oprasional }}{\text { Pendapatan Oprasional }} \times 100 \%
$$

Non Performing Loan (NPL) atau kredit bermasalah merupakan salah satu indikator kunci untuk menilai kinerja fungsi bank. Salah satu fungsi bank adalah sebagai lembaga intermediary atau penghubung antara pihak yang memiliki kelebihan dana dengan pihak yang membutuhkan dana.

NPL $=\frac{\text { Total NPL }}{\text { Total Kredit }} \times 100 \%$

\section{Net Interest Margin (NIM)}

NIM merupakan rasio antara pendapatan bunga terhadap rata-rata aktiva produktif. Pendapatan diperoleh dari bunga yang diterima dari pinjaman yang diberikan dikurangi dengan biaya bunga dari sumber dana yang dikumpulkan.

$\mathrm{NIM}=\frac{\text { Aktiva Produktif }}{\text { Pendapatan Bunga Bersih }} \times 100 \%$

\section{Capital Assets Ratio (CAR) terhadap Return On Asset (ROA)}

Menurut Dendawijaya (2015) Capital adequacy Ratio (CAR) merupakan rasio dari hasil perbandingan antara modal dan aktiva tertimbang risiko. Rasio yang menggambarkan penggunaan aktiva bank yang dapat mengakibatkan risiko (penyeretan, kredit, surat berharga dan tagihan pada bank) ikuti di biayai oleh dana modal bank selain di biayai pada bank lain seperti dana masyarakat, pinjaman(utang), dan lain-lain.

Maka hasil presentase CAR menggambarkan semakin besar modal yang dimiliki bank sehingga mempengaruhi tinggkat kepercayaan masyarakat yang berujung pada peningkatan laba bank (ROA). 
Kecukupan modal yang dimiliki oleh bank membuat para nasabah merasa aman untuk mempercayakan dananya. Dapat dsimpulkan bahwa CAR berbanding lurus atau sejalan dengan ROA.

$\mathrm{H}_{1}$ : CAR berpengaruh signifikan positif terhadap ROA.

Beban Operasional terhadap Pendapatan Operasional (BOPO) terhadap Return On Asset (ROA)

Pengaruh BOPO terhadap ROA Pendapatan operasional merupakan pendapatan utama bank yang berasal dari pendapatan bunga yang diperoleh dari penempatan dana dalam bentuk kredit dan pendapatan operasional lainnya .Rasio ini mencerminkan tingkat efisiensi bank dalam menjalankan operasionalnya. Bank yang efisien dalam menekan biaya operasionalnya akan dapat mengurangi kerugian akibat ketidakefisienan dalam mengelola usahanya sehingga laba yang diperoleh juga akan meningkat. Alasan ini yang menjadi dasar peneliti menentukan rasio BOPO menjadi variabel negatif, karena semakin rendah BOPO berarti semakin efisien bank tersebut dalam mengendalikan biaya operasionalnya.

$\mathrm{H}_{2}$ : Biaya Operasi dan Pendapatan Operasi (BOPO) berpengaruh negatif terhadap (ROA).

Non Forming Loan (NPL) terhadap Return On Asset (ROA)

Rasio NPL menunjukkan kemampuan manajemen bank dalam mengelola kredit bermasalah atas kredit yang diberikan bank. NPL merupakan presentase jumlah kredit bermasalah terhadap total kredit yang dikeluarkan oleh bank. Rasio NPL yang tinggi akan memperbesar biaya, sehingga berpotensi menyebabkan kerugian terhadap bank. Alasan ini yang menjadi dasar peneliti menentukan rasio NPL menjadi variabel negatif, karena semakin tinggi kredit bermasalah maka tinggi kemungkinan kerugian bank atau semakin rendah profitabilitas Berdasarkan pemaparan di atas, dapat dikembangkan hipotesis sebagai berikut :

$\mathrm{H}_{3}$ : Non Performing Loan (NPL)

Net Interest Margin (NIM) terhadap Return On Asset (ROA)

Pengaruh antara NIM dan ROA adalah negatif atau tidak searah. Hal ini dikarenakan jika NIM mengalami peningkatan maka akan semakin buruk kualitas pembiayaan bank tersebut. Kualitas pembiayaan yang memburuk akan menyebabkan jumlah pembiayaan bermasalah semakin meningkat sehingga bank nantinya akan mengeluarkan biaya yang lebih besar dibandingkan pendapatannya. Akibat dari kondisi tersebut laba bank menurun dan ROA menurun pula.

$\mathrm{H}_{4}$ : NPF secara parsial mempunyai pengaruh negatif yang signifikan terhadap ROA pada Bank Umum Syariah.

\section{Kerangka Pemikiran}

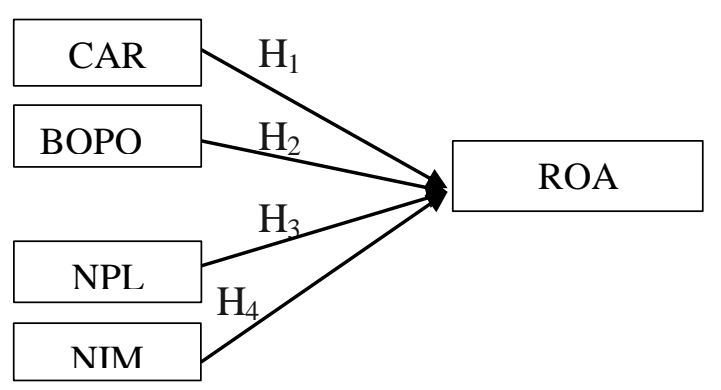




\section{METODE PENELITIAN}

Populasi adalah kumpulan dari semua objek atau individu yang memiliki karakteristik tertentu, jelas dan lengkap yang akan diteliti (bahan Penelitian). Populasi yang digunakan dalam penelitian ini adalah semua Bank umum Syariah di Indonesia yang terdaftar direktorat Bank Indonesia periode 2014-2018 yaitu sebanyak 16 Bank Umum syariah.

Pemilihan sampel dalam penelitian ini menggunakan metode purposive sampling, menurut Usman dan Akbar (2008) metode ini digunakan apabila anggota sampel yang dipilih secara khusus metode ini digunakan apabila anggota sampel yang dipilih secara khusus berdasarkan tujuan penelitian yaitu memilih karakteristik tertentu sebagai kunci untuk dijadikan sampel, sedangkan yang tidak masuk dalam karakteristik yang dijadikan sampel, sedangkan yang tidak dijadikan sampel. Adapun kriteria yang digunakan untuk menentukan sampel dalam penelitian ini, yaitu :

(a) Bank Indonesia menyediakan laporan keuangan secara lengkap selama periode 2014-2018 terkait dengan adanya nilai inflasi dan suku bunga.

(b) Bank Umum Syariah menyediakan laporan keuangan secara lengkap selama periode 2014-2018 terkait dengan nilai CAR.

(c) Laporan keuangan yang disediakan merpakan laporan keuangan tahunan pada periode 2014-2018 yang telah di publikasi di Bank Indonesia atau di Otoritas Jasa Keuangan.

(d) Bank Umum Syariah di Indonesia memiliki data yang dibutuhkan terkait pengukuran variabel-variabel yang digunakan untuk penelitian selama periode 2014-2018.
Berdasarkan metode Purposive Sampling tersebut, ada dua belas sampel yang digunakan dalam penelitian ini.

Analisis regresi berganda akan dilakukan bila jumlah variabel independennya minimal 2. Menurut Sugiyono (2014) persamaan regesi linier berganda yang ditetapkan adalah sebagai berikut :

$$
Y=a+b_{1 \times 1}+b_{2 \times 2}+b_{3 \times 3}+b_{4 \times 4+} €
$$

$\begin{array}{ll}\text { Keterangan : } & \\ \mathrm{Y} & =\text { ROA } \\ \mathrm{a} & =\text { Koefisien konstanta } \\ \mathrm{b} & =\text { Koefisien regresi } \\ \mathrm{x} 1 & =\mathrm{CAR} \\ \mathrm{x} 2 & =\mathrm{BOPO} \\ \mathrm{x} 3 & =\mathrm{NPL} \\ \mathrm{x} 4 & =\mathrm{NIM} \\ € & =\text { error }\end{array}$




\section{HASIL DAN PEMBAHASAN}

\section{Gambaran Umum Perusahaan}

Penelitian ini mengindentifikasi kinerja Bank Umum Syariah dan Bank Indonesia tahun 2014-2018. Objek penelitian terdiri dari 12 Bank Umum Syariah yang terdiri dari yaitu, Bank Muamalat Indonesia,
Victoria Syariah, Bank BRI Syariah, Jabar Banten Syariah, Bank Bni Syariah, Bank Syariah Mandiri, Mega Syariah, Panin Dubai Syariah, Syariah Bukopin, Bank Bca Syariah, Bank Tabungan Pensiunan Syariah, Maybank Syariah. Data yang digunakan adalah laporan keuangan triwulan pada periode 2014-2018.

Analisis Deskriptif Statistik

Tabel 1. Deskriptif Statistik

\begin{tabular}{cccc}
\hline & Mean & Std. Deviation & $\mathrm{N}$ \\
\hline $\mathrm{Y}$ & 2.3780 & 1.42197 & 35 \\
\hline $\mathrm{X}_{1}$ & 57.9591 & 223.28770 & 35 \\
\hline $\mathrm{X}_{2}$ & 67.2717 & 28.51630 & 35 \\
\hline $\mathrm{X}_{3}$ & 1.5454 & 1.34122 & 35 \\
\hline $\mathrm{X}_{4}$ & 6.1109 & 2.64603 & 35 \\
\hline
\end{tabular}

\section{Sumber : Data Olahan Microsft Excel, 2019}

Dengan data statistik di atas dapat disimpulkan bahwa:

1. Jumlah observasi perusahaan perbankan adalah sebanyak 35 data selama periode 2014 - 2018. Nilai rata - rata (mean) ROA sebesar 2,3780, dengan standar deviasinya sebesar 1,42197 , yang artinya nilai mean lebih kecil daripada standar deviasinya sehingga mengindikasikan hasil yang tidak baik karena semakin besarnilai standar deviasi maka semakin besar kemungkinan nilai riil menyimpang dari yang diharapkan.

2. Nilai rata - rata (mean) CAR sebesar 24,6777, maka Standar deviasinya sebesar 21,58912 , yang artinya nilai mean lebih besar dari pada nilai standar deviasinya sehingga mengindentifikasikan hasil sebaran data yang cukup baik. Hal tersebut dikarenakan standar deviasi adalah pencerminan penyimpangan yang sangat tinggi, sehingga data menunjukkan hasil yang normal dan tidak menyebabkan bias.

3. Nilai rata- rata (mean) $\mathrm{BOPO}$ sebesar 57,9591 dengan standar deviasinya sebesar 28.51630, yang artinya nilai mean lebih besar dari pada nilai standar deviasinya sehingga mengidentifikasikan hasil sebaran data yang cukup baik. Hal ini di karenakan standar deviasi adalah penyimpanan yang sangat tinggi, sehingga data menunjukkan hasil yang normal dan tidak menyebabkan bias.

4. Nilai rata - rata (mean) NPL sebesar 1,5454 dengan standar deviasinya sebesar 1,34122 , yang artinya nilai mean lebih besar dari pada nilai standar deviasinya sehingga mengidentifikasikan hasil sebaran data yang cukup baik. Hal ini di karenakan standar deviasi adalah penyimpanan yang sangat tinggi, sehingga data menunjukkan hasil yang normal dan tidak menyebabkan bias. 
5. Nilai rata - rata (mean) NIM sebesar 6,1109 dengan standar deviasinya sebesar 2,64603, yang artinya nilai mean lebih besar dari pada nilai standar deviasinya sehingga mengidentifikasikan hasil sebaran data yang cukup baik. Hal ini di karenakan standar deviasi adalah penyimpanan yang sangat tinggi, sehingga data menunjukkan hasil yang normal dan tidak menyebabkan bias.

\section{Uji Asumsi Klasik}

Uji Normalitas Data

\section{Uji Multikolonieritas Data}

Uji normalitas sebaran titik yang dimaksud adalah untuk mengetahui apakah skor variabel yang diteliti mengikuti distribusi normal atau tidak normal. Untuk mengetahui normal atau tidak normalnya sebaran titik datanya, menurut Hadi data dikatakan berdistribusi normal jika signifikan > 0,05, sebaliknya jika nilai signifikannya $<0,05$ maka sebarannya dinyatakan tidak normal. Dan dari penelitian ini dari data CAR, BOPO, NPL dan NIM terhadap ROA pola distribusi tidak normal, karena titik tidak mendekati garis diagonal.

Table 2. Uji Multikoloneritas

\begin{tabular}{cccc}
\hline Variabel & Tolerance & VIF & Ket \\
\hline $\mathrm{X}_{1}$ & 0,782 & 1,279 & Tidak Multikolonieritas \\
\hline $\mathrm{X}_{2}$ & 0,563 & 1,777 & Tidak Multikolonieritas \\
\hline $\mathrm{X}_{3}$ & 0,343 & 2,915 & Tidak Multikolonieritas \\
\hline $\mathrm{X}_{4}$ & 0,279 & 3,589 & Tidak Multikolonieritas \\
\hline
\end{tabular}

Sumber : Data Olahan SPSS, 2019

Berdasarkan tabel 2 di atas, dapat diketahui nilai Tolerance dan VIF untuk menghitung masing - masing penelitian sebagai berikut : (a) Nilai Tolerance untuk variabel $\mathrm{X}_{1}$ sebesar $0,782>0,10$ dan nilai VIF sebesar 1,279<10, sehingga variabel $X_{1}$ dinyatakan tidak terjadi gejala multikolonieritas, (b) Nilai Tolerance untuk variabel $\mathrm{X}_{2}$ sebesar $0,563>0,10$ dan nilai VIF sebesar 1,777 < 10, sehingga variabel $X_{2}$ dinyatakan tidak terjadi gejala multikolonieritas, (c) Nilai tolerance untuk variabel $\mathrm{X}_{3}$ sebesar $0,343>0,10$ dan nilai VIF sebesar 2,915< 10, sehingga variabel Suku Bunga dinyatakan tidak terjadi gejala multikolonieritas, (d) Nilai tolerance untuk variabel $\mathrm{X}_{4}$ sebesar $0,279>0,10$ dan nilai VIF sebesar 3,589 < 10, sehingga variabel
Suku Bunga dinyatakan tidak terjadi gejala multikolonieritas.

\section{Uji Heterokedasitas Data}

Uji heterokedasitas bertujuan untuk menguji apakah dalam model rergresi terjadi ketidaksamaan varian dari residual atau pengamatan kepengamatan lain. Jika varian dari satu pengamatan ke pengamatan yang lain tetap, maka disebut homoskedastisitas. Model regresi yang baik adalah yang homoskedastisitas atau yang tidak terjadi heteroskedastisitas. Maka dalam penelitian ini bahwa titik menyebar baik di atas maupun di bawah angka nol dan tidak membentuk suatu pola tertentu maka dapat dikatakan tidak terjadi heteroskedastisitas. 


\section{Uji Autokorelasi}

\begin{tabular}{ccccc}
\multicolumn{5}{c}{ Tabel 3. Uji Autokorelasi } \\
\hline Variabel & DL & DW & DU & Kesimpulan \\
\hline $\mathrm{X}_{1} \mathrm{X}_{2} \mathrm{X}_{3}$ & -2 & 2,077 & +2 & Tidak Terjadi Autokorelasi \\
\cline { 3 - 5 }
\end{tabular}

Sumber : Data Olahan SPSS, 2019

Uji autokorelasi bertujuan untuk menguji apakah ada korelasi antara variabel itu sendiri. untuk menguji keberadaan autokorelasi dalam penelitian ini di gunakan metode Durbin-Watson test, dimana pengambilan keputusan ada tidaknya autokorelasi adalah sebagai berikut : (1) Angka D-W di bawah -2 berarti ada autokorelasi positif, (2) Angka D - W di antara -2 sampai +2, maka tidak ada autokorelasi, (3)Angka D $-\mathrm{W}$ di atas +2 berarti ada autokorelasi negatif. Jadi dalam penelitian ini nilai D -W yaitu 2,316, melebihi +2 maka model regresi linier berganda dalam penelitian ini terjadi autokolerasi.

\section{Uji Kelayakan Model}

Tabel 4. Uji F (Uji Simultan)

\begin{tabular}{cccc}
\hline Variabel & Thitung $_{\text {hesimpulan }}$ & Sig. & Kerpengaruh Signifikan \\
\hline $\mathrm{X}_{1} \mathrm{X}_{2} \mathrm{X}_{3} \mathrm{X}_{4}$ & 15,036 & 0,000 & Berper
\end{tabular}

Sumber : Data Olahan SPSS, 2019

Berdasarkan tabel 10 di atas, di dapat

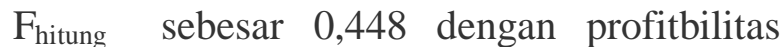
sebesar 0,720 yang nilainya dibawah 0,05. Hal in menunjukan bahwa semua variabel independen yaitu CAR, BOPO, NPL, dan NIM berpengaruh signifikan secara simultan (bersama - sama) terhadap ROA pada Bank Umum Syariah dan Bank Indonesia.

\section{Uji Koefisien Determinasi}

Tabel 5. Koefisien Determinasi

\begin{tabular}{ccc}
\hline Variabel & $\mathbf{R}_{\text {square }}$ & Persen \\
\hline $\mathrm{X}_{1} \mathrm{X}_{2} \mathrm{X}_{3} \mathrm{X}_{4}$ & 0,623 & 62,3 \\
\hline
\end{tabular}

Sumber : Data Olahan SPSS, 2019

Berdasarkan tabel 11 diatas variabel CAR,BOPO, NPL, dan NIM berpengaruh terhadap ROA sebesar 0,623 atau 62,3\% sedangkan sisanya sebesar $37,7 \%$ di

\section{Uji Analisis Regresi Linier Berganda}

pengaruhi oleh faktor lainyang tidak dimasukan kedalam model misalnya inflasi, suku bunga, LDR dan sebagainya.

Tabel 6. Regeresi Linear Berganda

\begin{tabular}{ccl}
\hline Variabel & B & Kesimpulan \\
\hline (Constantat) & 1,353 & Berpengaruh positif \\
\hline CAR & 0,000 & Berpengaruh positif \\
\hline BOPO & -005 & Berpengaruh negative \\
\hline NPL & $-0,356$ & Berpengaruh negative \\
\hline NIM & 0,311 & Berpengaruh positif \\
\hline & Sumber : Data Olahan SPSS, 2019
\end{tabular}


$\mathrm{Y}=\mathrm{a}+\mathrm{b}_{1 \times 1}+\mathrm{b}_{2 \times 1}+\mathrm{b}_{3 \times 3}+\mathrm{b}_{4 \times 4}+€$

$\mathrm{Y}=1,353+0,000-005-0,356+0,311+€$

Dari tabel di aas dapat disimpulkan bahwa : (a) Konstanta sebesar 1,353 artinya CAR, BOPO, NPL, dan NIM tidak ada maka ROA sebesar 1,457, (b) CAR berpengaruh positif terhadap ROA sebesar 0,000 ini dapat diartinya setiap kenaikan satu satuan CAR akan penyusutan ROA sebesar 0,000. Dan sebaliknya, setiap penurunan satu satuan ROA, akan menurunkan ROA sebesar 0,000, (c) BOPO berpengaruh negatif terhadap ROA sebesar -
005 artinya setiap kenaikan satu satuan BOPO akan meningkat ROA sebesar -005. Dan sebaliknya, setiap penurunan BOPO, akan menurun BOPO sebesar -005, (d) NPL berpengaruh positif terhadap ROA sebesar 0,356 artinya setiap kenaikan satu satuan NPL akan Meningkatkan ROA sebesar 0,356. Dan sebaliknya, setiap penurunan NPL, akan menurunan NPL sebesar $-0,356$, (e) NPL berpengaruh positif terhadap ROA sebesar 0,311 artinya setiap kenaikan satu satuan NIM akan Meningkatan ROA sebesar $-0,311$. Dan sebaliknya, setiap penurunan NIM, akan menurunan NIM sebesar -0,311.

\section{Uji Hipotesis (Uji t)}

Table 7. Uji T

\begin{tabular}{cccc}
\hline Variabel & $\mathbf{t}_{\text {hitung }}$ & Sig. & Kesimpulan \\
\hline $\mathrm{X}_{1}$ & 0,144 & 0,887 & Tidak signifikan \\
\hline $\mathrm{X}_{2}$ & $-0,704$ & 0,596 & Tidak signifikan \\
\hline $\mathrm{X}_{3}$ & $-1,866$ & 0,072 & Tidak signifikan \\
\hline $\mathrm{X}_{4}$ & 2,900 & 0,007 & Tidak signifikan \\
\hline
\end{tabular}

Sumber : Data Olahan SPPS, 2019

Berdasarkan angka $t_{\text {tabel }}$ dengan ketentuan $\alpha=0,05$ sehingga diperoleh nilai $\mathrm{t}_{\text {tabel }}$ sebesar 2,002, maka dapat diketahui pengaruh masing - masing variabel sebagai berikut:

(a). Variabel CAR terhadap ROA

Dari tabel koefesien diperoleh nilai $\mathrm{t}_{\text {hitung }}=0,144$ yang artinya $\mathrm{t}_{\text {hitung }}<\mathrm{t}_{\text {tabel }}(0,144$ $<2,002$ ) dengan signifikan 0,887 > 0,05 maka Ho diterima dan $\mathrm{H} \alpha$ di tolak artinya parsial tidak dapat pengaruh positif tidak signifikan antara CAR terhadap ROA atau CAR berpengaruh signifikan positif terhadap ROA.

(b). Variabel BOPO terhadap ROA

Dari tabel koefesien diperoleh nilai $\mathrm{t}_{\text {hitung }}=0,704$ yang artinya $\mathrm{t}_{\text {hitung }}<\mathrm{t}_{\text {tabel }}$ $(0,704<2,002)$ dengan signifikan 0,596> 0,05 maka Ho diterima dan $\mathrm{H} \alpha$ di tolak artinya parsial tidak dapat pengaruh negatif tidak signifikan antara BOPO terhadap ROA atau BOPO berpengaruh signifikan positif terhadap ROA.

(c). Variabel NPL terhadap ROA

Dari tabel koefesien diperoleh nilai $\mathrm{t}_{\text {hitung }}=-1,866$ yang artinya $\mathrm{t}_{\text {hitung }}<\mathrm{t}_{\text {tabel }}(-$ $1,866<2,002)$ dengan tidak signifikan 0,072> 0,05 maka Ho diterima dan $\mathrm{H} \alpha$ ditolak artinya parsial tidak dapat pengaruh negatif tidak signifikan antara NPL terhadap ROA atau NPL berpengaruh signifikan positif terhadap ROA.

(d). Variabel NIM terhadap ROA

Dari tabel koefesien diperoleh nilai $\mathrm{t}_{\text {hitung }}=2,900$ yang artinya $\mathrm{t}_{\text {hitung }}<\mathrm{t}_{\text {tabel }}$ $(2,900<2,002)$ dengan tidak signifikan $0,007>0,05$ maka Ho diterima dan $\mathrm{H} \alpha$ ditolak artinya parsial tidak dapat pengaruh negatif tidak signifikan antara NPL terhadap 
ROA atau NPL berpengaruh signifikan positif terhadap ROA.

\section{KESIMPULAN}

Berdasarkan hasil analisis data dan pembahasan yang sudah dijelaskan, dapat ditraik kesimpulan bahwa Capital Adequacy Ratio (CAR) berpengaruh positif signifikan positif terhadap ROA, Beban Operasional terhadap Pendapatan Oprasional (BOPO) berpengaruh negatif tidak signifikan, Non Forming Loan (NPL)berpengaruh negatif tidak signifikan, Net Interest Margin berpengaruh negatif tidak signifikan.

\section{DAFTAR PUSTAKA}

Dendawijaya, Lukman. 2017. Manajemen Perbankan, Ghalia Indonesia. Jakarta.

Greuning, H. Van, Iqbal, Z., 2011. Ananlisis Risiko Perbankan Syariah (Risk Analysis for Islamic Banks). Penerbit Salemba Empat. Jakarta.

Laily, Wahidda Fitri Nur. 2014. Pengaruh Rasio CAMELS Terhadap Tingkat Profitabilitas Pada Bank Umum Syariah. Skripsi Sarjana tak diterbitkan. STIE Perbanas Surabaya.

Sugiyono. 2014. Metode Penelitian Pendidikan Pendekatan Kuantitatif, Kualitatif, dan $R \& D$. Alfabeta. Bandung

Usman, Husaini, dan Akbar, Purnomo Setiadi. 2008. Pengantar Statistika. Bumi Aksara. Jakarta. 